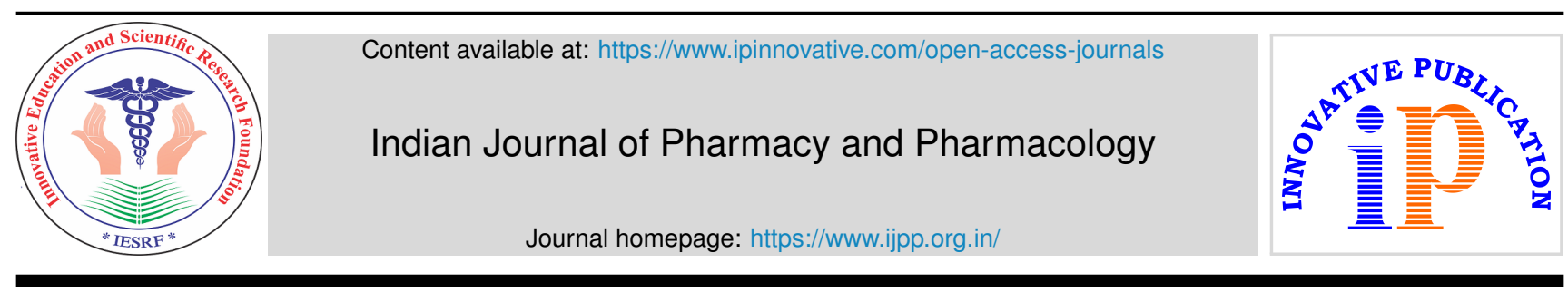

\title{
Editorial
}

\section{Corona vaccine approach}

\author{
Sunil Chaudhry ${ }^{1, *}$ \\ ${ }^{1}$ Honorary Médical Director, Bioclinitech Technologies Pvt Ltd, Mumbai, India \& GPATtutor.com
}

\section{A R T I C L E I N F O}

Article history:

Received 20-07-2021

Accepted 10-08-2021

Available online 04-09-2021
This is an Open Access (OA) journal, and articles are distributed under the terms of the Creative Commons Attribution-NonCommercial-ShareAlike 4.0 License, which allows others to remix, tweak, and build upon the work non-commercially, as long as appropriate credit is given and the new creations are licensed under the identical terms.

For reprints contact: reprint@ipinnovative.com
"I have no special talents, I am only passionately curious - Albert Einstein

Dear readers, effective control of COVID -19 through vaccination remains effective measure to control mass viral spread. Curiosity and integrity of researchers will strive to control this devastating disease.

Treatment of any form of illness, invokes physicians curiosity for bestowing proper remedy. The prophylactic remedy is proper vaccination.

The infectivity of the SARS-CoV-2 virus is very high compared to other corona viruses reported so far, an effective vaccine is the best way to contain the rapidly escalating proliferation of this infection.

A COVID \& \#8209;19 vaccine is a vaccine intended to provide acquired immunity against severe acute respiratory syndrome corona virus 2 (SARS\&\#8209;CoV\&\#8209;2), the virus that causes corona virus disease 2019 (COVID\&\#8209;19).

Coronaviruses have a large $(30+\mathrm{kb})$ single-stranded positive sense RNA genome encased by a helical nucleocapsid $(\mathrm{N})$ and an outer envelope comprised of matrix protein $(\mathrm{M})$, envelope protein $€$ and spike proteins (S). S protein was found to elicit neutralising antibody and is a major target antigen for vaccine development.

Currently, 39 coronavirus vaccines are in different stages of clinical trials globally, out of which 6 are from India, 13

\footnotetext{
* Corresponding author.

E-mail address: sunil.r.chaudhry @gmail.com (S. Chaudhry).
}

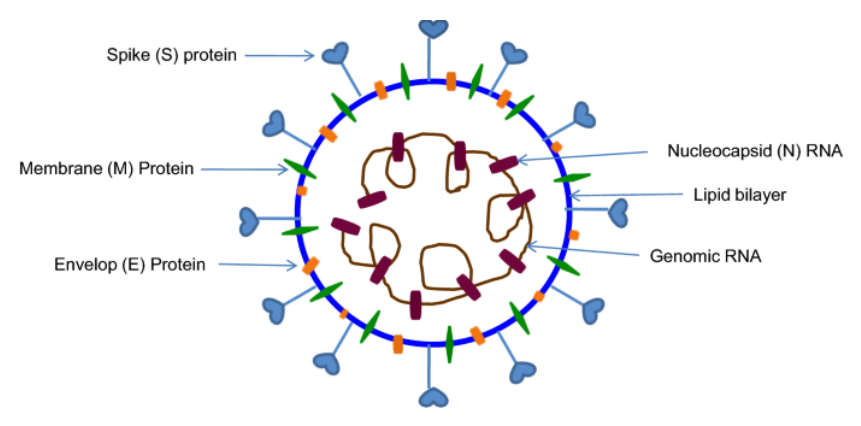

Fig. 1:

from China, and 20 from other countries.Currently available vaccines in Indian market

Covishield is the better known. It's a version of the Oxford University-AstraZeneca vaccine that was found to have an average efficacy of $70.4 \%$ in a peer reviewed study. A study has found $0.03 \%$ of people caught COVID after the 2nd dose of Covishield and $0.04 \%$ tested positive after the 2nd dose of Covaxin. Covaxin will have to gather more data and needs to be presented at WHO so that it is marketed globally.

The most common side effect is soreness at the site of injection. Other side effects include fatigue, headache, muscle aches, chills, joint pain, and possibly some fever. Side effects were more frequent after the second dose in the vaccine trials. 
Table 1: Difference between sputnik v and the other two vaccines

Sputnik
Developed by
gamaleya research
institute of
epidemiology in
association with Dr.
Reddy's
91.6 percent effective

The interval between the 2 doses is likely to be 21 days up to 8 weeks.

\section{Covishield and covaxin}

Covishield is developed by the SII, Oxford university and astrazeneca whereas covaxin is developed by bharat biotech and ICMR

Covishield can be up to $90 \%$ effective and covaxin has been found to be $78-81 \%$ effective. In completed Phase III trial, Covaxin is $77.8 \%$ effective.

The gap between the doses of covishiled and covaxin are respectively 12-16 weeks and 4-6 weeks

Table 2: Introduction of Pfizer/BioNTech and moderna vaccines in indian market

\begin{tabular}{|c|c|c|}
\hline Characteristics & $\begin{array}{l}\text { Pfizer/ BioNtech } \\
\text { vaccine }\end{array}$ & Moderna vaccine \\
\hline Type of vaccine & mRNA (BNT162b2) & $\begin{array}{l}\text { mRNA } \\
\text { (mRNA-1273) }\end{array}$ \\
\hline Dose & $\begin{array}{l}\text { Each dose contains } \\
30 \mu \mathrm{g}(0.3 \mathrm{~mL})\end{array}$ & $\begin{array}{l}\text { Each dose } \\
\text { contains } 50 \mu \mathrm{g} \\
(0.5 \mathrm{~mL})\end{array}$ \\
\hline $\begin{array}{l}\text { Number of } \\
\text { injections }\end{array}$ & $\begin{array}{l}2 \text { injections, given } \\
21 \text { days apart }\end{array}$ & $\begin{array}{l}2 \text { injections, given } \\
28 \text { days apart }\end{array}$ \\
\hline Effectiveness & $\begin{array}{l}95 \% \text { in preventing } \\
\text { the SARS-COV- } \\
\text { 2infection } 14 .\end{array}$ & $\begin{array}{l}94.5 \% \text { in } \\
\text { preventing the } \\
\text { SARS-COV-2 } \\
\text { infection }\end{array}$ \\
\hline Storage & $\begin{array}{l}\text { Multiple dose vials } \\
\text { are stored } \\
\text { between }-80^{\circ} \mathrm{C} \text { and } \\
-60^{\circ} \mathrm{C}\end{array}$ & $\begin{array}{l}\text { Multiple-dose } \\
\text { vials are stored } \\
\text { between- } 25^{\circ} \text { and } \\
-15^{\circ} \mathrm{C}\end{array}$ \\
\hline
\end{tabular}

Coadministration of vaccines: If required, COVID-19 vaccine and other vaccines should be separated by an interval of at least 14 days. Interchangeability of COVID19 vaccines is not permitted: Second dose should also be of the same COVID-19 vaccine which was administered as the first dose.

Contraindications: Persons with history of Anaphylactic or allergic reaction to a pervious dose of COVID-19 vaccine or Immediate or delayed-onset anaphylaxis or allergic reaction to vaccines or injectable therapies, pharmaceutical products, food-items etc.

The dataset tracks the total number of COVID-19 vaccinations administered in each country, broken down by first and second doses (where national data is available), and derived daily vaccination rates and population-adjusted figures
Corona vaccine dashboard: By the end of this year, India is likely to have nearly dozen vaccines. New intranasal vaccine BBV154 creates an immune response at the site of infection (in the nasal mucosa). This helps to block both infection and transmission of Covid-19. This will reduce the gap between supply and demand and also bring down the prices. On 21st august 2021, drug controller general of India (DCGI) granted emergency use approval to Zydus Cadila's needle-free vaccine, ZyCoV-D, the world's first ever DNA based vaccine against the SARs-COV-2 virus. Uses jet injector. Valid for children above 12 years.

\section{Which vaccine has greatest global reach?}

Number of countries and territories using each vaccine

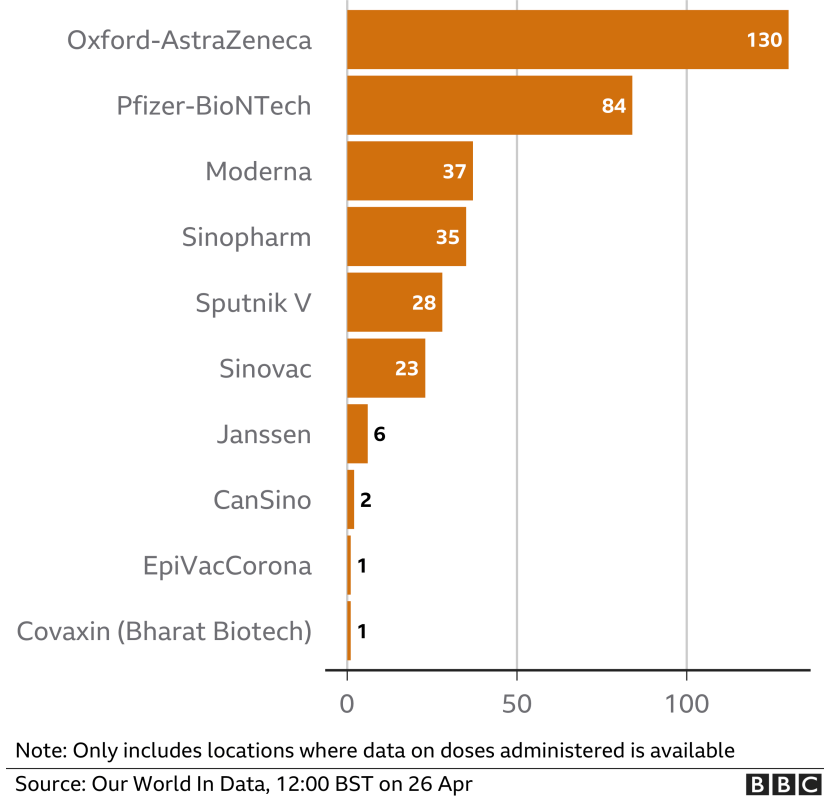

Fig. 2:

Corona virus has crescendo and decendo pattern as the mutant strains keep appearing, leading to optimal hit at peak. Option to vaccinate more population with lead to mass immunity conferring bodys ability to fight infection.

We as responsible citizens, must abide to government's vaccination program and proper use of measures like masks, adhering to distance philosophy for long duration will make this virus extinct. Time is only solution.

\section{Author biography}

Sunil Chaudhry, Honarary Medical Director, Bioclinitech Technologies Pvt Ltd Mumbai India

Cite this article: Chaudhry S. Corona vaccine approach. Indian J

Pharm Pharmacol 2021;8(3):177-178. 